\title{
THE EFFECTIVENESS OF DISCOVERY LEARNING MODEL IN IMPROVING STUDENTS' FICTION WRITING
}

\author{
Isah Cahyani \\ Universitas Pendidikan Indonesia \\ E-mail: isahcahyani@upi.edu \\ Lia Yulindaria \\ Universitas Pendidikan Indonesia \\ E-mail: liayulindaria@gmail.com
}

\begin{abstract}
APA Citation: Cahyani, I., \& Yulindaria, L. (2018). The effectiveness of discovery learning model in improving students' fiction writing. Indonesian Journal of Learning and Instruction, $1(1), 37-46$.
\end{abstract}

\begin{abstract}
Writing skill becomes a concern nowadays since it is an important skill in communication and becomes the hallmark of a creative, imaginative, and educated nation. Yet, in fact, students' writing skills are generally low which can be seen from the lack of quality of writing produced. This is caused by some factors, including the lack of time allocation provided by the teacher to practice writing, the lack of teachers' creativity in using learning models that can stimulate students to write, and the low of students' reading habits. Hence, this study aims to identify the effectiveness of Discovery Learning (DL) model in improving students' fiction writing. This research is a quasi experimental with nonequivalent control group design. The sample of research was the fourth grader of elementary school in Purwakarta sub-district. The data in this research were collected through writing test, observation, and interview. Moreover, students' writing skills were assessed by using writing rubric which has been validated by expert lecturers. Further, the data were then analyzed by using inference statistics including normality test, homogeneity test, and t-test. The results revealed that discovery learning model is effective in improving students' fiction writing which can be seen from students' post test score. This is because discover learning model allows students to explore, classify, and utilize more data to improve their imagination, their vocabulary selection, and their creativity as well.
\end{abstract}

Keywords: discovery learning model; writing skill; fiction writing.

\section{INTRODUCTION}

Reading and writing skills are important things to consider in today's age of technology and information because writing is an important ability in communicating to convey an intention and purpose (Nurhayati, 2015; Soleha, 2014; Tarigan, 2008). Besides, writing is one of skills that can improve student creativity (Munawaroh, 2013; Silalahi \& Haryadi, 2015). Further, writing skill is regarded as a hallmark of an educated person or nation (Soleha, 2014; Supriyadi, 2013).

As a skill, writing is a difficult and complex skill that is difficult to master. This problem is considered normal, because writing is not a hereditary ability, nor is it merely the activities of stringing words and sentences, but also expressing and developing the mind in a regular writing (Cahyani, 2012). Writing is said to be complicated because writing skills have six dimensions, namely 1) quality and content scope (quality and scope of content); 2) organization and presentation of content; 3 ) style and appropriateness; 4) grammatical forms (grammatical features); 5) spelling; and 6) handwriting and neatness (Rahman, 2013; Ismail, 2011).

Fiction Story is a story containing narratives that are made based on the 
The effectiveness of discovery learning model in improving students' fiction writing

imaginary fantasy or imagination. Fiction or custom stories are usually in the form of novels and short stories (Frigg, 2010; Sterling, 2009). Fictional stories try to enliven the feelings or arouse the emotions of its readers. A fictional story as a literary work is a tool for instilling morale to students or children according to its characteristics (Frigg, 2010; Skolnik, 1973). Children around 5-12 years old need concrete understanding. This is in line with Piaget's opinion that the maturity level of children aged 7-12 years is called the concrete stage in which the maturity of children tends to be limited to concrete objects that can be seen and touched, while the abstract concept is still difficult to accept (Wood, 2008).

Writing fiction stories will give some benefits for students, such as giving students the opportunity to be a young writer, allowing them to elaborate their imagination, and motivating them to appreciate literary works. Yet, teaching fiction writing is not an easy task since writing, especially fiction writing is not yet a habit in our society. The writing culture among students is still very low (Rakhmat, 2012; Sumasari, 2014).

Discovery learning model is one of the learning models applied in the 2013 curriculum because it supports the application of scientific approach and can bring students to think high level (Higher Order Thinking Skill/HOTS). The DL model is one of learning models that is expected to develop selflearning (Hermann, 1969; Rumelhart \& Zipser, 1985). This model seeks to understand how we better understand ourselves, take responsibility for our education, and learn to reach or even transcend our current development in order to become stronger, more sensitive, and more creative in looking for a more prosperous life (Marzano, 2011).

Discovery learning model, according to Alma et al. (2010), is based on a belief in the framework of independent student development. This model requires active participation in scientific investigation. This is in line with the opinion that the child must play an active role in learning in the classroom. When applying the learning model, the teacher acts as a mentor by giving students the opportunity to actively learn. Here, the teacher must be able to guide and direct the student's learning activities according to the purpose (Alfieri, Brooks, Aldrich, \& Tenenbaum, 2011).

Discovery learning is expected to be an alternative to improve learning outcomes and students' ability in understanding the concept of fiction writing as well as minimizing the difficulty level of writing. In addition, with the Discovery Learning model, it is expected to bring the creativity and imagination of students as well as allow them to be able to write better fiction stories.

\section{METHOD}

This research is a quasi experimental with nonequivalent control group design by employing two variables, namely the learning model $(\mathrm{X})$ as independent variable and the skill of fiction writing (Y) as the dependent variable (Setyanto, 2006; Supranto, 2000). The instruments used in this research were test, observation, questionnaire, and interview. The collected data were then analyzed by using software of MS Excel 2013 and Predictive Analytics Software (PASW Statistics 21) or IBMSPSS version 21.0. The data in the form of test result of fictional story writing skill is analyzed quantitatively by using statistical test.

\section{RESULTS AND DISCUSSION \\ Initial ability profile of CIRC (Cooperative Integrated Reading Composition)}

The results showed that the initial skill profile of writing group of DL $0 \%$ learning model was in the category of very good, $0 \%$ was in good category, $3.23 \%$ was in enough category, and $96,77 \%$ were in the category need guidance. Table 1 below presents a complete profile of the initial capability of writing the DL group. 
Table 1. Initial writing capabilities profile of DL group

\begin{tabular}{clccc}
\hline No & Criteria & Interval & Frequency & Percentage \\
\hline 1 & Very Good & $90-100$ & 0 & 0.00 \\
2 & Good & $80-89$ & 0 & 0.00 \\
3 & Enough & $70-79$ & 1 & 3.33 \\
4 & Need Guidance & $<70$ & 29 & 96.67 \\
& Total & & 30 & 100.00 \\
\hline
\end{tabular}

When described in graphical form, it is presented as in Figure 1 below.

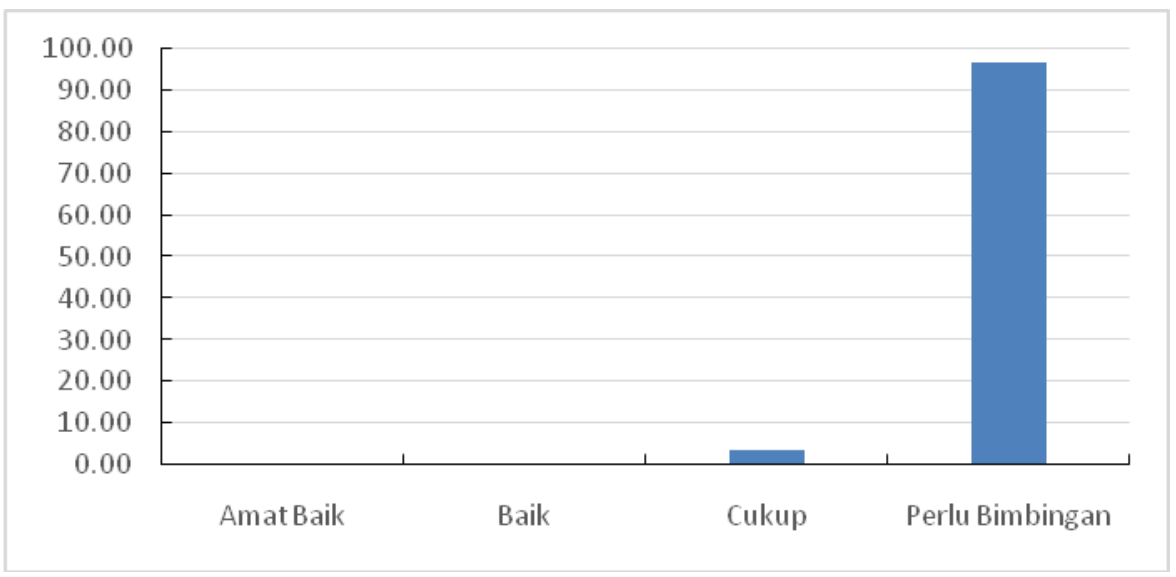

Figure 1. Initial writing capabilities profile of DL group

The number of students in the category need guidance indicates that the writing ability of students is still low so that reinforcement is needed on the indicators of writing skills, especially on indicators of style and storyline development, grammatical, spelling, and neatness of writing. Furthermore, if the description of the initial ability to write the DL group is outlined based on the indicator, then presented as in Table 2 below.

Table 2. Initial skills indicator profile of DL group

\begin{tabular}{|c|c|c|c|c|c|}
\hline No & Indicator & Criteria & Interval & Frequency & Percentage \\
\hline \multirow[t]{4}{*}{1} & Scope and Content & Very good & $90-100$ & 2 & 6.67 \\
\hline & & Good & $80-89$ & 14 & 46.67 \\
\hline & & Enough & $70-79$ & 0 & 0.00 \\
\hline & & Need Guidance & $<70$ & 14 & 46.67 \\
\hline \multirow[t]{4}{*}{2} & Organization and & Very good & $90-100$ & 0 & 0.00 \\
\hline & Content View & Good & $80-89$ & 9 & 30.00 \\
\hline & & Enough & $70-79$ & 0 & 0.00 \\
\hline & & Need Guidance & $<70$ & 21 & 70.00 \\
\hline \multirow[t]{4}{*}{3} & Development of & Very good & $90-100$ & 0 & 0.00 \\
\hline & Styles and Story & Good & $80-89$ & 1 & 3.33 \\
\hline & Flow & Enough & $70-79$ & 0 & 0.00 \\
\hline & & Need Guidance & $<70$ & 29 & 96.67 \\
\hline \multirow[t]{4}{*}{4} & Grammatical & Very good & $90-100$ & 0 & 0.00 \\
\hline & & Good & $80-89$ & 1 & 3.33 \\
\hline & & Enough & $70-79$ & 0 & 0.00 \\
\hline & & Need Guidance & $<70$ & 29 & 96.67 \\
\hline \multirow[t]{4}{*}{5} & Spelling & Very good & $90-100$ & 0 & 0.00 \\
\hline & & Good & $80-89$ & 2 & 6.67 \\
\hline & & Enough & $70-79$ & 0 & 0.00 \\
\hline & & Need Guidance & $<70$ & 28 & 93.33 \\
\hline
\end{tabular}


Isah Cahyani \& Lia Yulindaria

The effectiveness of discovery learning model in improving students' fiction writing

\begin{tabular}{|c|c|c|c|c|c|}
\hline 6 & $\begin{array}{l}\text { Posts, Tidiness, } \\
\text { and Hygiene }\end{array}$ & $\begin{array}{l}\text { Very good } \\
\text { Good } \\
\text { Enough } \\
\text { Need Guidance }\end{array}$ & $\begin{array}{c}90-100 \\
80-89 \\
70-79 \\
<70\end{array}$ & $\begin{array}{c}0 \\
2 \\
0 \\
28\end{array}$ & $\begin{array}{c}0.00 \\
6.67 \\
0.00 \\
93.33 \\
\end{array}$ \\
\hline
\end{tabular}

Based on Table 2, it can be seen that the scope and content indicator show that $6.67 \%$ are in very good category, $46.67 \%$ are in good category, $0 \%$ is in enough category, and $46.67 \%$ are in need guidance category. The magnitude of both categories indicates that when writing, students have written the intrinsic element of the story in the form of title/theme, background, figure, plot, complete message, and content fit properly. In the organizational indicator and content display, it is found that $0 \%$ is in very good category, $30 \%$ are in good category, $0 \%$ is in enough category, and $70 \%$ are in need guidance category. The magnitude of the category needs guidance on this indicator indicates that the students in this class have not been able to decipher the ideas that are interconnected with each other and yet balanced between the opening, fill and closing sections. Students have not been able to compose fictional essays from the beginning to the closing.

The writing is not yet orderly, neat, clear, and logical. Coherence between parts is not good enough. In the indicator of style and story development, it is found that $0 \%$ is in very good category, $3.33 \%$ are in good category, $0 \%$ are in enough category, and $96,67 \%$ are in need guidance category. The size of the category needs guidance on this indicator shows that the ability to apply and write sentences of words and variations of phrases used is still very low. Subjection uses only a few simple words to describe the fiction story he wrote. The development of a story that contains the creativity and imagination of the author is still very shallow and simple. In the grammatical indicator it is found that $0 \%$ is in very good category, $3.33 \%$ are in good category, $0 \%$ is in enough category, and $96,67 \%$ are in need guidance category. The magnitude of the categories need guidance on this indicator indicates that the effective use of sentences, the correspondence between sentences with each other, and the selection of the right word or diction is still not mastered.

In the spelling indicator, it is found that $0 \%$ is in very good category, $6.67 \%$ are in good category, $0 \%$ is in enough category, and $93,33 \%$ are in need guidance category. The size of the categories need guidance on this indicator indicates that students have not mastered the rules of writing, writing is often confusing, a lot of spelling errors, and there is often the use of less precise punctuation. In the indicator of writing, tidiness, and cleanliness, it is found that $0 \%$ is in very good category, $6.67 \%$ is in good category, $0 \%$ is in enough category, and $93,33 \%$ is in need guidance category. The size of the category need guidance on this indicator indicates that the student's writing is still a lot of unreadable letters, letter size and position of the letter is not as it should be, and the writing sheet that looks dirty. When being described in graphical form, it is presented as in Figure 2 below.

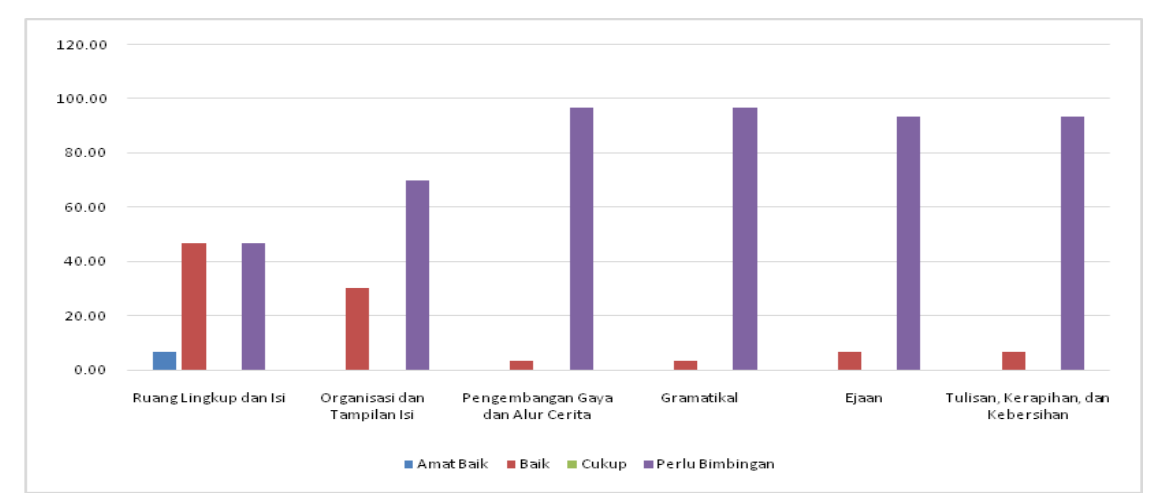

Figure 2. Initial skills indicator profile of DL group 
Indonesian Journal of Learning and Instruction Volume 1, Issue 1, April 2018

\section{The final capability profile of DL model} group

The results showed that the final writing ability profile of DL group are 73,33\% learning model group is in very good category,
p-ISSN 2614-8250, e-ISSN 2614-5677

https://journal.uniku.ac.id/index.php/IJLI

$26.67 \%$ are in good category, $0 \%$ is in enough category, and $0 \%$ is in need guidance category. The following 3 presents the complete profile of the end group writing DL capabilities.

Table 3. Final writing capabilities profile of DL group

\begin{tabular}{clccc}
\hline No & Criteria & Interval & Frequency & Percentage \\
\hline 1 & Very Good & $90-100$ & 22 & 73.33 \\
2 & Good & $80-89$ & 8 & 26.67 \\
3 & Enough & $70-79$ & 0 & 0.00 \\
4 & Need Guidance & $<70$ & 0 & 0.00 \\
& Total & & 30 & 100.00 \\
\hline
\end{tabular}

When being described in graphical form, it is presented as in Figure 3 below.

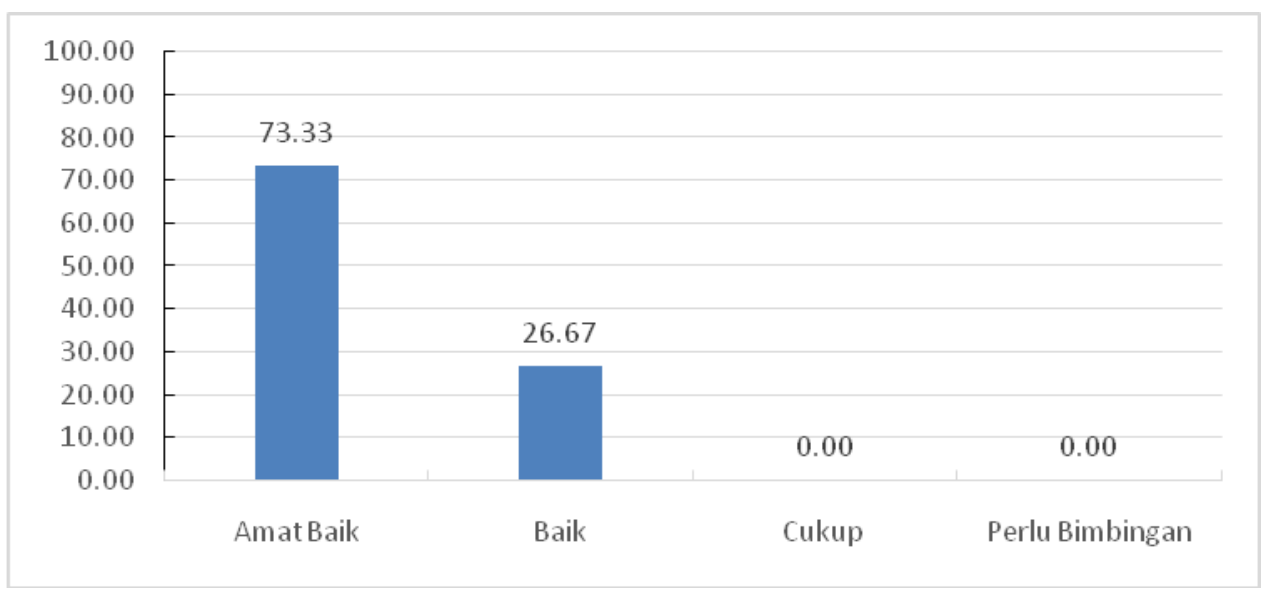

Figure 3. Final writing capabilities profile of DL group

Furthermore, if the description of the final writing capability of the DL group is outlined based on the indicator, it is presented as in Table 4 below.

Table 4. Final writing capabilities profile of DL group

\begin{tabular}{|c|c|c|c|c|c|}
\hline No & Indicator & Criteria & Interval & Frequency & Percentage \\
\hline \multirow[t]{4}{*}{1} & Scope and & Very good & $90-100$ & 26 & 86.67 \\
\hline & Content & Good & $80-89$ & 4 & 13.33 \\
\hline & & Enough & $70-79$ & 0 & 0.00 \\
\hline & & Need Guidance & $<70$ & 0 & 0.00 \\
\hline \multirow[t]{4}{*}{2} & Organization and & Very good & $90-100$ & 25 & 83.33 \\
\hline & Content View & Good & $80-89$ & 5 & 16.67 \\
\hline & & Enough & $70-79$ & 0 & 0.00 \\
\hline & & Need Guidance & $<70$ & 0 & 0.00 \\
\hline \multirow[t]{4}{*}{3} & Development of & Very good & $90-100$ & 11 & 36.67 \\
\hline & Styles and Story & Good & $80-89$ & 19 & 63.33 \\
\hline & Flow & Enough & $70-79$ & 0 & 0.00 \\
\hline & & Need Guidance & $<70$ & 0 & 0.00 \\
\hline \multirow[t]{4}{*}{4} & Grammatical & Very good & $90-100$ & 15 & 50.00 \\
\hline & & Good & $80-89$ & 15 & 50.00 \\
\hline & & Enough & $70-79$ & 0 & 0.00 \\
\hline & & Need Guidance & $<70$ & 0 & 0.00 \\
\hline \multirow[t]{2}{*}{5} & Spelling & Very good & $90-100$ & 15 & 50.00 \\
\hline & & Good & $80-89$ & 15 & 50.00 \\
\hline
\end{tabular}


Isah Cahyani \& Lia Yulindaria

The effectiveness of discovery learning model in improving students' fiction writing

\begin{tabular}{|c|c|c|c|c|c|}
\hline \multirow{6}{*}{6} & \multirow{6}{*}{$\begin{array}{l}\text { Posts, Tidiness, } \\
\text { and Hygiene }\end{array}$} & Enough & $70-79$ & 0 & 0.00 \\
\hline & & Need Guidance & $<70$ & 0 & 0.00 \\
\hline & & Very good & $90-100$ & 16 & 53.33 \\
\hline & & Good & $80-89$ & 14 & 46.67 \\
\hline & & Enough & $70-79$ & 0 & 0.00 \\
\hline & & Need Guidance & $<70$ & 0 & 0.00 \\
\hline
\end{tabular}

Based on Table 4, it is found that in the scope and content indicator, $86.67 \%$ are in very good category, $13.33 \%$ are in good category, $0 \%$ is in enough category, and $0 \%$ is in need guidance category. In the organizational indicator and content patch, it is found that $83.33 \%$ are in very good category, $16.67 \%$ are in good category, $0 \%$ is in enough category, and $0 \%$ is in need guidance category. In the indicator of style and story development, it is found that $36.67 \%$ are in very good category, $63.33 \%$ are in good category, $0 \%$ is in enough category, and $0 \%$ is in need guidance category. In the grammatical indicator, it is found that $50 \%$ are in very good category, $50 \%$ are in good category, $0 \%$ is in enough category, and $0 \%$ is in need guidance category. In the spelling indicator, it is found that $50 \%$ are in very good category, $50 \%$ are in good category, $0 \%$ is in enough category, and $0 \%$ is in need guidance category. In the indicator of writing, tidiness, and cleanliness, it is found that $53.33 \%$ are in very good category, $46.67 \%$ are in good category, $0 \%$ is in enough category, and $0 \%$ is in need guidance category. When being described in graphical form, it is presented as in Figure 4 below.

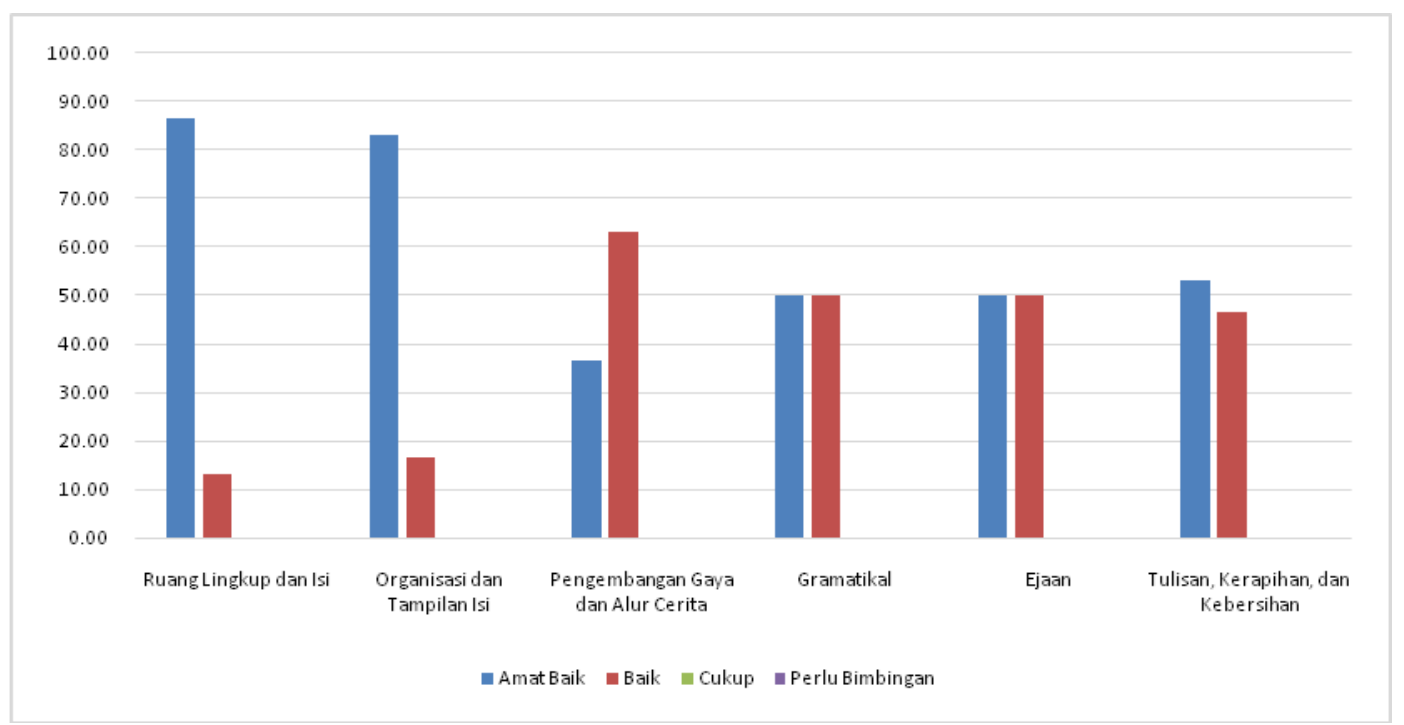

Graph 4. Final writing capabilities profile of DL group

This DL model is able to improve students' writing skill because it gives students the opportunity to conduct their own experiments and practice in writing. As Hoogeveen (2016) state students should be given plenty of opportunities to experiment with physical objects, supported by interactions with many elements, and assisted by teacher questions. Teachers should provide stimulus to students to interact with the environment and actively seek and find things in the environment. The DL model provides students with opportunities to actively and effectively learn. The DL model provides a range of learning conditions and situations in the form of direct and actual experience involvement designed by the teacher (Humphrey, 2014; Anam, 2015; Ausubel, 1971). The DL model directs students to gain more experience and effectiveness through direct and personal engagement. 
According to Dewey, learning is the process of doing, reacting, discovering, and experiencing. Students obtain learning outcomes based on activities that have been done (Bower, 2014). In addition, Dewey also explained that true education takes place through educational experience. The experiences that students have experienced have an important role in the formation of cognitive knowledge in the minds of students.

Learning based on experience also conforms to the Ausubel concept of meaningful learning. According to Ausubel, meaningful learning will occur if the new information received by students has a close relationship with existing concepts that have been received previously and stored in the cognitive structure. Ausubel explains that experience gives students a way to find understanding instead of accepting understanding (Dahar, 2011). Therefore, DL affects the writing skills of students. Each experience gives meaning so that students can write ideas about the information and experience it (Bicknell-Holmes \& Hoffman, 2000; Bruner, 1961).

Another impact of this DL model is that students follow the lesson with enthusiasm and joy. Enthusiasm when learning occurs because students gain a pleasant learning experience such as visiting the library, conducting interviews, and finding information through surfing the internet. Student involvement in learning will provide experience so that students can construct their own knowledge. This is in line with Kolb's theory that learning is a process for building knowledge through a series of concrete and abstract experiences (Tomkins \& Ulus, 2016).

The learning process takes place internally so that the learning process leads to the achievement of the objectives and curriculum so the teacher must plan with a systematic learning experience that allows changes in student behavior in accordance with what is expected. Teachers' efforts to create conditions that enable student learning to take place are optimally visible in DL learning. Learning with the Discovery
Learning model facilitates a learning process that enables students to develop themselves, their knowledge, understanding, behavior and skills they master (Holland, Holyoak, Nisbett, $\&$ Thagard, 1986; Mayer, 2004). Teachers are in charge of helping students by manipulating the environment so that students can learn easily. Teachers held the selection of various strategies and learning models that exist and most likely to optimize student learning process (Munawaroh, 2013).

Based on analysis, it was revealed that learning with the DL model has a tremendous impact on improving students' fiction writing skills. By applying the DL learning model, students perform increased levels of exploration, classification, and greater use of data as well as their imagination, selection of vocabulary, and their creativity as well.

\section{CONCLUSION}

Based on the theories that have been presented and coupled with the analysis of research data, it can be concluded that the empirical model of Discovery Learning can improve students' fiction writing skills significantly, especially on organizational indicators and content display, the development of style and storyline, grammatical, spelling, tidiness and cleanliness of writing. The Discovery Learning model enables students to grow as they provide opportunities for students to conduct their own experiments, allowing students to actively and effectively learn, providing a range of learning conditions and situations in the form of direct and actual experience engagement. In addition, the Discovery Learning model allows students to follow the lesson with enthusiasm and joy. Students' involvement in learning will provide experience so that students can construct their knowledge.

Teachers play a crucial role on the success of students in learning, where teachers have to manipulate the environment so that students can learn easily. Teachers need to make an election to the various strategies and models of learning that exist. Based on the result of the research, the researcher can provide the 


\section{Isah Cahyani \& Lia Yulindaria}

The effectiveness of discovery learning model in improving students' fiction writing

following suggestions; 1) the principal is expected to participate in training, seminar, or implement lesson study about cooperative learning model so that it can be implemented in the teaching and learning process in the classroom; 2) The Discovery Learning model should be implemented in a class with heterogeneous student composition; and, 3) giving more opportunities for students to write stories because students' writing will get much better by practicing.

\section{REFRENCES}

Alfieri, L., Brooks, P. J., Aldrich, N. J., \& Tenenbaum, H. R. (2011). Does discovery-based instruction enhance learning? Journal of Educational Psychology, 103(1), 1-18.

Alma, B., et al. (2010). Guru profesional menguasai metode dan terampil mengajar. Bandung: Alfabeta.

Anam, R. S. (2015). Efektivitas dan pengaruh model pembelajaran inkuiri pada pembelajaran IPA di sekolah dasar. Mimbar Sekolah Dasar Upi, 2(1).

Ausubel, D. P. (1971). Limitations of learning by discovery. In Readings in Secondary School Mathematics, 20 (pp. 197-213). doi: $10.1177 / 019263656104526904$.

Bicknell-Holmes, T., \& Hoffman, P. S. (2000). Elicit, engage, experience, explore: Discovery learning in library instruction. Reference Services Review, 28, 313-322. doi: 10.1108/00907320010359632.

Bower, G. G. (2014). Theory and practice: Utilizing Dewey's experiential learning theory to implement a 5k road race. Journal of Hospitality, Leisure, Sport \& Tourism Education, 15(1), 61-67

Bruner, J. (1961). The act of discovery. Harvard Educational Review. Retrieved from Http://scholar.google.com/scholar?hl=en\&btng=se arch\&q=intitle:the+act+of+discovery $\#$.

Cahyani, I. (2012). Pembelajaran menulis berbasis karakter dengan pendekatan experiental learning. Prodi Pendidikan Dasar Sps UPI. Bandung.

Dahar, R.W. (2011). Teori-teori belajar dan pembelajaran. Jakarta: Erlangga.

Frigg, R. (2010). Models and fiction. Synthese, 172(2), 251-268. doi: 10.1007/S11229-009-9505-0.

Holland, J. H., Holyoak, K. J., Nisbett, R. E., \& Thagard, P. R. (1986). Induction: Processes of inference, learning, and discovery. computational models of cognition and perception. doi: 10.1109/Mex.1987.4307100.

Hoogeveen, M., \& Gelderen, A. (2016). Writing with peer response using different types of genre knowledge: Effects on linguistic features and revisions of sixth grade writers. The Journal of Educational Research, 20(1), 1-14.
Humphrey, K. R. (2014). Lessons learned from experiential group work learning. Social Work With Group, 37, 67-72.

Marzano, R. J. (2011). The perils and promises of discovery learning. Educational Leadership, 69(1), 86.

Mayer, R. E. (2004). Should there be a three-strikes rule against pure discovery learning? American Psychologist, 59(1), 14-19. doi: 10.1037/0003066x.59.1.14.

Munawaroh, R. (2013). Pengaruh model pembelajaran menulis terbimbing terhadap kreativitas dan keterampilan menulis narasi siswa sekolah dasar. Jurnal Pedagogic Pendidikan Dasar, 1(3).

Ismail, N. A. B. (2011). Penguasaan penulisan karangan bahasa melayu dari perspektif komunikatif. Seminar Penyelidikan 2011 Zon Timur Di Ipg Kampus Sultan Mizan, Besut, Terengganu, (1970), $1-12$.

Nurhayati, N. (2015). Model pembelajaran menulis ceria pendek dengan menggunakan teknik brainwriting yang berorientasi pada kreativitas siswa. Jurnal Pendidikan Bahasa, Sastra Indonesia dan Pembelajarannya, 1(1).

Rakhmat, I. (2012). Memilah fakta dan fiksi dalam kitab suci : Sebuah usaha hermeneutis. Kanz Philosophia : A Journal for Islamic Philosophy And Mysticism, 2(2), 221. doi: 10.20871/Kpjipm.V2i2.31.

Rahman. (2013). Pengembangan kemampuan menulis kalimat pada siswa kelas. Bandung: UPI Press.

Rumelhart, D. E., \& Zipser, D. (1985). Feature discovery by competitive learning. Cognitive Science, 9(1), 75-112. doi: 10.1016/S03640213(85)80010-0.

Silalahi, R., \& Haryadi, H. (2015). Peningkatan pembelajaran menulis puisi bebas melalui media lagu medley siswa kelas VIII SMP Sintang. Lingtera, 2(1), 73-83. doi: 10.21831/LT.V2I1.5409.

Skolnik, H. (1973). Truth in fiction. Journal of Chemical Documentation, 13(3), 106. doi: 10.1021/C160050a001

Soleha, Y. S. (2014). Pembelajaran Menulis deskripsi dengan teknik pemandangan indah pada siswa sekolah dasar negeri percobaan (SDNP) Cileunyi, Kabupaten Bandung. Metalingua, Jurnal Penelitian Bahasa, 2(1).

Sterling, B. (2009). Design fiction. Interactions, 16(3), 20. doi: 10.1145/1516016.1516021.

Sumasari, Y. J. (2014). Analisis unsur-unsur intrinsik dalam hikayat cerita taifah. Desember, 4(2), 20893973.

Supranto, J. (2000). Teknik sampling untuk survey dan eksperimen. Jakarta: Rineka Cipta.

Supriyadi, S. (2013). Strategi learning community untuk meningkatkan keterampilan menulis wacana deskriptif siswa SD. Jurnal Ilmu Pendidikan, 18(1), 36-47. doi: 10.17977/JIP.V18I1.3381. 
Indonesian Journal of Learning and Instruction Volume 1, Issue 1, April 2018

Tarigan, H. G. (2008). Menulis sebagai suatu keterampilan berbahasa. Bandung: Angkasa.

Tomkins, L., \& Ulus, E. (2016). Oh was that "experiential learning"?! Spaces, synergies and
p-ISSN 2614-8250, e-ISSN 2614-5677

https://journal.uniku.ac.id/index.php/IJLI

surprises with Kolb's learning cycle. Management Learning, 47(2), 158-178.

Wood, J. (2008). How fiction works. Retrieved from: https://doi.org/doi 10.1093/escrit/cgp014. 
Isah Cahyani \& Lia Yulindaria

The effectiveness of discovery learning model in improving students' fiction writing 